JP3I (Jurnal Pengukuran Psikologi dan Pendidikan Indonesia), 9(2), 2020, 68-74

D0l: http://dx.doi.org/10.15408/p33iv9i2.XXXXX

http://journal.uinjkt.ac.id/index.php/jp3i

\title{
Surviving the Covid-19 Pandemic: Analysis of the Grit Factor in Students
}

\author{
Sovi Septania, Sulastri \\ Faculty of Psychology, Universitas Muhammadiyah Lampung, Indonesia \\ sovi.septania@gmail.com
}

\begin{abstract}
Covid-19 pandemic had a massive impact to all aspects in society, including university students. Challenge of online study and family's economic pressure forced them to turn this situation into strategy to survive amid several limitations. This strategy known as grit. Grit is a psychological contruct which first introduced by Duckworth (2007). Its definition is expanding through the years, but it keeps referring to its initial definition as perseverance and willingness to achieve long-term goals. Grit scale consist of 16 items with two main aspects, consistency in interest and perseverance in action. Purpose of this study was to analyze which factors in grit which mostly impact to survival strategy in students. This research involved 318 university students using purposive sampling method. Data which have been collected was categorized into five main factors which relate to students's survival strategy consist of consitency, efforts to maintain goals, encounter challenges, executing task and hardwork. Final result using factor analysis with the help of SPSS 25.0 program, showed that those factor reduce into two main factor consist of goal clarity and persistency.
\end{abstract}

Keywords: grit, factor analysis, pandemic Covid-19. 


\section{Introduction}

The Covid-19 pandemic has occurred around the world. The impact generated by this pandemic was still felt until June 2020 with data on confirmed positive cases of corona reaching 55,092 patients throughout Indonesia (Ministry of Health, 2020). The impact of a pandemic is not only on the aspects of the vulnerability of medical transmission, but also on the economic impact up to education. According to Kurnia (2020), based on data from the Ministry of Manpower as of April 2020, as many as 2,084,593 workers from 116,370 companies were sent home and were laid off (PHK). Especially education, starting from March 2020 based on the Circular of the Ministry of Education and Culture No. 4 of 2020 concerning the implementation of education in the Covid-19 emergency period in the form of distance or online. The sudden change in learning methods has academic and psychological effects on students (Jamaluddin, Ratnasih, Gunawan \& Paujiah, 2020). These two conditions are certainly quite a challenge for students to survive in the midst of a pandemic with all its limitations, both academically and economically.

One of the psychological constructs related to long-term human survival known as grit. The initial research of grit was conducted by Duckworth, Peterson, Matthew \& Kelly (2007). The study defines grit as perseverance and consistent for long-term goals in a long period of time. Based on this definition, the grit aspect consists of consistency behavior towards an attraction and persevered in action. Someone with a high grit level, it will increase workability towards challenges that arise during the process, being able to maintain effort and able to consistently maintain certain interests over a long period of time, despite facing failures and obstacles in the process.

The definition of grit differs from several other psychological constructs, such as perseverance, resilience, hardiness, ambition and need for achievement. Perseverance is more related to resilience and determination in achieving goals, although faced with challenges, problems and confusion, while grit is argued as a character of perseverance itself. Grit allows individuals to be persistent in achieving goals even with long-term challenges (Duckworth, et al., 2007).

Grit is a psychological construct that is closely related to success. Previous studies has analyzed extensively on the role of grit as a predictor of success (Poropat, 2009; Valiente, Lemer-Chalfant, Swanson \& Reiser, 2008; Valiente, Lemer-Chalfant \& Swanson, 2010). Eskreis-Winkler, Shulman, Beal \& Duckworth (2014) stated that employee turnover can be predicted through a person's grit behavior more than other predictors. In several other contexts, grit has been shown to positively affect performance. Some examples in previous research such as soldiers who are able to complete army special operations forces (ARSOF) education had a higher grit level than others, sales employees with higher grit will be more able to survive in their jobs, students with higher grit levels will be able to graduate with better grades. Furthermore, level of grit in marriage is one of the reasons why men are able to survive in marriage. Duckworth, Kirby, Tsukayama, Berstein and Ericson (2011) state that competitors who have a higher level of grit in the national spelling bee competition will be able to practice longer, thus increasing their ranking at the end of the competition. Supported by research from Vallerand, Houlfort and Forest (2014) which empirically proved that identification of success predictors where grit is one of the strongest success factors among others.

Several studies conducted previously provide reinforcement of the concept of grit related to academic and social success. In the context of student academic success, it showed that grit has a positive correlation with student career decision making (Septania \& Khairani, 2019) and negatively correlated with student procrastination behavior (Septania, Ishar \& Sulastri, 2018). Socially, grit becomes a rovering system or activator in completing the selfless helping behavior of young volunteers (Septania \& Shah, 2020). 
However, research focusing on the main factors in students to survive and achieve success during the pandemic period analyzed through grit behavior still needs further development. This is the main objective of research as well as adding to empirical research in the psychological realm which has an impact on increasing the positive character of students, especially during pandemic-covid 19.

\section{Methods}

\section{Research Instrument}

Research instrument in this study using grit scale made by Duckworth, et al. (2007). This scale adapted into Indonesian language and had been used in several studies as collecting data tool. The grit scale using Likert model which is stated to be able to measure a person's perceptions and attitudes about a social phenomenon. In compiling items as research instruments that are expressed in the form of questions or statements, it is necessary to translate variables into behavioral indicators.

The grit scale originally made by Duckworth, et al. (2007) using two main aspects, namely consistency of interest and persistence in action. The grit scale consisted of 16 total items with 9 favorable items and 7 unfavorable items. Behavioral aspects formulated in a favorable direction which contains the appropriate behavior concept or supports the attributes being measured. In contrast to writing items that are written in the favorable direction, it can also be written in the unfavorable direction, which does not support the behavioral characteristics desired by the behavior indicators (Azwar, 2013). This instrument was initially still in foreign languages which were adapted with some adjustments to language and cultural characters in Septania's (2015) research.

The scale will have four types of answer choices, namely: Very Suitable (SS), Suitable (S), Not Suitable (TS), Very Unsuitable (STS). The scoring will be based on the nature of the statement. The parameter used is that the higher the score on the grit scale, the higher the level of grit that is owned. The lower the score, the lower the level of grit one has.

\section{Research Subject}

This study involved 318 subjects with purposive sampling technique using two main criteria such as, students aged 17-25 years and doing online learning during the pandemic. Demographic data can be seen in table 1.

Table 1. Subject Demographic

\begin{tabular}{cccc}
\hline \multicolumn{2}{c}{ Demografi } & Jumlah & \% \\
\hline Gender & Female & 187 & $59 \%$ \\
& Male & 131 & $41 \%$ \\
\hline \multirow{6}{*}{ Age } & 17 tahun & 1 & $0 \%$ \\
& 18 tahun & 12 & $4 \%$ \\
& 19 tahun & 38 & $12 \%$ \\
& 20 tahun & 65 & $20 \%$ \\
& 21 tahun & 72 & $23 \%$ \\
& 22 tahun & 50 & $16 \%$ \\
& 23 tahun & 34 & $11 \%$ \\
& 24 tahun & 21 & $7 \%$ \\
& 25 tahun & 25 & $8 \%$ \\
\hline
\end{tabular}

Source: Research Data (2020) 
Female subjects are more than male subjects, although the percentage was still said to be balanced. The age range of subjects was evenly distributed from 17-25 years, with the most age being 21 years. Demographically, it can be categorized that the research subject has met the planned criteria.

\section{Data Analysis}

The research method used in this research is factor analysis using the SPSS 25.0 program. The main purpose of factor analysis is to define the structure of a data matrix and analyze the structure of the relationship (correlation) between a large number of variables (test scores, test items, questionnaire answers) by defining a set of similarities of variables or dimensions known as factors (Ghozali,2011).

Basic assumption for factor analysis is where data matrix must have sufficient correlation in order to be analyzed further. Minimum score for correlation value must be above 0.30 to be sufficiently continue to factor analysis. Correlations between variables can be analyzed by calculating partial correlation between variables through the anti-image correlation matrix which contains negative values from partial correlation using SPSS. In interpreting the factors, factor rotation is carried out in order to clarify the variables that enter certain factors.

\section{Result and Discussion}

The first step as a prerequisite for performing factor analysis is to calculate the correlation between the variables under study. The correlation matrix was obtained using the Kaiser-Meyer-Olkin (KMO) Measure of Sampling Adequacy (MSA) test with the results shown in Table 2.

Table 2. Kaiser-Meyer-Olkin (KMO)

\begin{tabular}{lrr}
\hline \multicolumn{3}{c}{ KMO and Bartlett's Test } \\
\hline Kaiser-Meyer-Olkin Measure of Sampling Adequacy. & 0.653 \\
& Approx. Chi-Square & 300.679 \\
\cline { 2 - 3 } Bartlett's Test of Sphericity & df & 10 \\
& Sig. & 0.000 \\
\hline
\end{tabular}

Kaiser-meyer-olkin (KMO) test above show the KMO-MSA value of $0.653(>0.50)$ and the Bartlett's Test of Sphericity value with a significance value of $0.000(p<0.05)$, thus the process of factor analysis is continued since the data meet the testing prerequisites.

To analyze and determine which variables are feasible in factor analysis, an anti-image correlation test is carried out. The results of this test can be seen in Table 3. MSA results obtained in the anti-image correlation, showed that the MSA consistency results are 0.669 , goal clarity is 0.620 , encounter challenges are 0.703 , executing tasks are 0.590 and hard-work is 0.807 . By the results of MSA which $>0.50$, factor analysis process can be continued. 
Tabel 3. Anti-Image Matrices

\begin{tabular}{ccccccc}
\hline & & $\begin{array}{c}\text { Zscore } \\
\text { (Consistency) }\end{array}$ & $\begin{array}{c}\text { Zscore } \\
(\text { Goal) }\end{array}$ & $\begin{array}{c}\text { Zscore } \\
\text { (Challenge) }\end{array}$ & $\begin{array}{c}\text { Zscore } \\
\text { (Executing } \\
\text { Task) }\end{array}$ & $\begin{array}{c}\text { Zscore } \\
\text { (Hardwork }\end{array}$ \\
\hline \multirow{3}{*}{ Anti-image } & (Consistency) & 0.852 & -0.074 & -0.216 & 0.058 & -0.129 \\
Covariance & (Goal) & -0.074 & 0.540 & -0.152 & -0.325 & -0.068 \\
& (Exallenge) & -0.216 & -0.152 & 0.803 & 0.031 & -0.087 \\
& (Hardwork) & -0.129 & -0.068 & -0.087 & -0.130 & -0.130 \\
Anti-image & (Consistency) & $0.669^{\mathrm{a}}$ & -0.109 & -0.261 & 0.082 & -0.154 \\
Correlation & (Goal) & -0.109 & $0.620^{\mathrm{a}}$ & -0.231 & -0.578 & -0.101 \\
& (Challenge) & -0.261 & -0.231 & $0.703^{\mathrm{a}}$ & 0.045 & -0.107 \\
& (Executing Task) & 0.082 & -0.578 & 0.045 & $0.590^{\mathrm{a}}$ & -0.188 \\
& (Hardwork) & -0.154 & -0.101 & -0.107 & -0.188 & $0.807^{\mathrm{a}}$ \\
\hline
\end{tabular}

The next step is by analyzing the total variance explained to determine the value of each variable. There are two kinds of analysis conducted, namely initial eigenvalues and extraction sum of squared loadings. Based on the results of initial eigenvalues which value should be $>1$. Component 1 show 2.209 score become the first factor which able to explain $44.182 \%$ of the variation. The eigenvalues for component 2 showing 1.071 score become second factor which able to explain $21.413 \%$ of the variation. If the two factors are added together, the total factor able to explain $65.595 \%$ of the variation. Components 3,4 , and 5 are not calculated due to the underscore of eigenvalues result $(<1)$. The results for the total variance explained can be seen in Table 4 .

Table 4. Total Variance Explained

\begin{tabular}{|c|c|c|c|c|c|c|c|c|c|}
\hline \multirow{2}{*}{ Comp. } & \multicolumn{3}{|c|}{ Initial Eigenvalues } & \multicolumn{3}{|c|}{$\begin{array}{c}\text { Extraction Sums of Squared } \\
\text { Loadings } \\
\end{array}$} & \multicolumn{3}{|c|}{$\begin{array}{c}\text { Rotation Sums of Squared } \\
\text { Loadings } \\
\end{array}$} \\
\hline & Total & $\begin{array}{c}\% \text { of } \\
\text { Variance }\end{array}$ & $\begin{array}{c}\text { Cumulative } \\
\% \\
\end{array}$ & Total & $\begin{array}{c}\% \text { of } \\
\text { Variance }\end{array}$ & $\begin{array}{c}\text { Cumulative } \\
\%\end{array}$ & Total & $\begin{array}{c}\% \text { of } \\
\text { Variance }\end{array}$ & $\begin{array}{c}\text { Cumulative } \\
\%\end{array}$ \\
\hline 1 & 2.209 & 44.182 & 44.182 & 2.209 & 44.182 & 44.182 & 1.851 & 37.017 & 37.017 \\
\hline 2 & 1.071 & 21.413 & 65.595 & 1.071 & 21.413 & 65.595 & 1.429 & 28.577 & 65.595 \\
\hline 3 & .737 & 14.731 & 80.325 & & & & & & \\
\hline 4 & .638 & 12.754 & 93.079 & & & & & & \\
\hline 5 & .346 & 6.921 & 100.000 & & & & & & \\
\hline
\end{tabular}

Component matrix analysis is performed to show the correlation value between each variable and the established factors. Meanwhile, to ensure which variable enter into which factor group by using the results of the rotated component matrix analysis, the results can be seen in Table 5 .

Table 5. Rotated Component Matrix

\begin{tabular}{ccc}
\hline & \multicolumn{2}{c}{ Component } \\
& 1 & 2 \\
\hline Zscore (Consistency) & 0.021 & 0.846 \\
Zscore (Goal) & 0.839 & 0.212 \\
Zscore (Challenge) & 0.232 & 0.733 \\
Zscore (Executing_Task) & 0.900 & -0.033 \\
Zscore (Hardwork) & 0.533 & 0.361 \\
\hline
\end{tabular}


Based in above result, first factor consists of goal, executing task and hardwork. Whilst, second factor consist of consistency and challenge. Component transformation matrix showed that correlation score for first factor amounting to 0.828 while second factor amounting to 0.561 . Since correlation value $>0.50$, it can be concluded that these two factors are feasible to summarize the five variables analyzed. The results of the component transformation matrix can be seen in Table 6 .

Table 6. Component Transformation Matrix

\begin{tabular}{ccc}
\hline Component & 1 & 2 \\
\hline 1 & 0.828 & 0.561 \\
2 & -0.561 & 0.828 \\
\hline
\end{tabular}

The overall results of the analysis above, show that the five initial variables analyzed consist of goal clarity, executing complete task, hard-work, consistency and encounter challenges which finally divided into 2 (two) main factors, namely the clarity of the final goal (goal, executing complete task, hard-work) and constancy factors (consistency and encounter challenges).

The first factor which includes the clarity of the final goal is able to explain $44.182 \%$ of student survival during pandemic covid-19, while the second factor which includes persistence is able to explain $21.413 \%$ of student survival. In total, those two factors are able to explain $65.595 \%$ of student survival during the pandemic. Based on this, it can be concluded that students who are able to survive are those who have clear final goals and are determined to achieve these goals with all the existing limitations.

Firmness is related to one's mental state. Research conducted by (Aubrey, Rich \& Eric, 2020) states that after controlling for age and gender, a person's mental ability affects $15.2 \%$ of the consistency of final goals and $13.1 \%$ of one's persistence. This is reinforced by the latest research from Mondak (2020) which states that persistence and consistency greatly contribute to success at work and at school.

\section{Conclusion}

The results of factor analysis above, obtained 2 (two) main factors that affect student survival during the pandemic as measured based on grit level data. The first factor consists of goals, executing tasks and hard-work, while the second factor consists of consistency and encounter challenges. The first factor is closely related to the goal clarity to be achieved (44.182\%), while the second factor is closely related to the persistency to achieve these goal $(21.413 \%)$. Based on these results, students will be better able to survive during the Covid-19 pandemic because they do not lose their final goal in education. The end goal becomes very important because it is the beginning and end of an achievement. This goal becomes stronger when students are persistent in achieving these goals. When students do not have clear goals or move between goals, students tend to be fragile and easier to sway when faced with challenges. Persistence in achieving goals will be a strengthening force to survive in the midst of a pandemic.

\section{Acknowledgment}

Authors would like to thank to Minister of Research and Technology Republic of Indonesia for the research funding through Penelitian Dosen Pemula Scheme in 2020. This article is an additional research outcome regarding measuring instrument used in the main research. The authors also would like to expressed gratitude to Universitas Muhammadiyah Lampung for the support and kind assistance during the research process. 


\section{References}

Aubrey, Newland., Rich, Gitelson., Eric, Legg. (2020). Examining the relationship between mental skills and Grit in Senior Olympic Athletes. Journal of Aging \& Physical Activity, 28(4), 658-667.

Azwar, Saifuddin. (2013). Penyusunan Skala Psikologi (edisi 2). Yogyakarta: Pustaka Pelajar.

Duckworth, A.L., Peterson, C., Matthews, M.D., \& Kelly, D.R. (2007). Grit: perseverance processes and passion for long-term goals. Journal of Personality and Social Psychology, 9(6), 1087-1101. https://doi.org/10.1037/0022-3514.92.6.1087.

Ducworth, A.L., Kirby, T., Tsukayama, E., Berstein, H., \& Ericson, K.A. (2011). Deliberate practice spells success: Why grittier competitors triumph at the national spelling bee. Social Psychology \& Personality Science, 2, 174-181.

Eskreis-Winkler, L., Shulman, E.P., Beal, S.A., \& Duckworth, A.L. (2014). The grit effect: predicting retention in the military, the workplace, school, and marriage. Journal of Personality Science and Individual Differences, 5(36), 1-12. https://doi.org/10.3389/fpsyg.2014.00036.

Ghozali, Imam. (2011). Aplikasi Multivariate dengan Program IBM SPSS. Semarang: Badan Penerbit Universitas Diponegoro.

Jamaluddin, Dindin., Ratnasih, Teti., Gunawan, Heri., \& Paujiah, Epa. (2020). Pembelajaran daring masa pandemik Covid-2019 pada calon guru: hambatan, solusi dan proyeksi. Karya Ilmiah, Lembaga Penelitian dan Pengabdian Kepada Masyarakat, UIN Sunan Gunung Djati.

Karunia, Ade Miranti. (6 Juli 2020). Dikutip dari url. https://money. kompas.com/read/2020/ 04/23/174607026/dampak-covid-19-menaker-lebih-dari-2-juta-pekerja-di-phk-dan-dirumahkan.

Ministry of Health (6 Juli 2020). Dikutip dari website https://covid19.kemkes.go.id/situasi-infeksiemerging/info-corona-virus/situasi-terkini-perkembangan-coronavirus-disease-covid-19-30-juni2020/\#.XwKPVJMzZQI.

Mondak, Jeffrery J. (2020). Citizen Grit: Effects of domain-specificity, perseveranse and consistency on political judgment. Journal of Personality and Individual Differences, September 2020 163, DOI. 10.1016/j.paid.2020.110059.

Poropat, A.E. (2009). A meta-analysis of the five-factor model of personality of academic performance. Psychology Buletin, 135, 322-338. DOI. 10.1037/a0014996.

Septania, Sovi. (2015). Peran kepemimpinan otentik terhadap grit yang dimediasi oleh keterpercayaan (trustworthiness) perusahaan. Tesis, Magister Profesi Psikologi, Universitas Gadjah Mada.

Septania, Sovi., Ishar, Meilia., \& Sulastri. (2018). Pengaruh grit terhadap prokrastinasi mahasiswa fakultas psikologi universitas muhammadiyah lampung. Prosiding Seminar Nasional Psikologi 2018, 16-28.

Septania, Sovi \& Khairani. (2019). Pengaruh grit dan gender dalam pengambilan keputusan karir mahasiswa. Jurnal Tajdid, 22(1), 19-27. https://doi.org/10.15548/tajdid.v22i1.279.

Septania, Sovi \& Khairani. (2020). Muda, berani dan tanpa pamrih: karakter grit pada perilaku ta'awun relawan muda muhammadiyah. Jurnal Sains Psikologi, 9 (2): 15-25.

Valiente, C., Lemery-Chalfant, K., Swanson, J., \& Reiser, M. (2008). Prediction's of children academic's competence from their effortful control, relationship and classroom participation. Journal Educational Psychology, 100, 67-77. https://doi.org/10.1037/0022-0663.100.1.67.

Valiente, C., Lemery-Chalfant, K., \& Swanson, J. (2010). Prediction's of kindergartner's academic achievement from their effortful control and emotionally evidence for direct and moderated relations. Journal Educational Psychology, 102, 550-560. https://doi.org.10.1037/a0018992. 